Jurnal Kependudukan Indonesia | Vol. 11 No. 2 Desember 2016 | 119-132

JURNAL KEPENDUDUKAN INDONESIA

p-ISSN : 1907-2902 (Print)

e-ISSN : 2502-8537 (Online)

\title{
SATU DEKADE PEMBANGUNAN SUMBER DAYA MANUSIA \\ DI WILAYAH PESISIR: CAPAIAN DAN TANTANGAN (KASUS PULAU MAPUR, KABUPATEN BINTAN)
}

\section{(ONE DECADE OF HUMAN RESOURCES DEVELOPMENT IN THE COASTAL AREAS: ACHIEVEMENTS AND CHALLENGES (CASE OF MAPUR ISLAND, BINTAN REGENCY))}

\author{
Widayatun \\ Pusat Penelitian Kependudukan-Lembaga Ilmu Pengetahuan Indonesia \\ Korespondensi Penulis: wida1960@yahoo.com
}

\begin{abstract}
The coastal areas of Indonesia are rich of natural resources. However, the resources have not been utilized optimally due to several factors, including the low quality of human resources. People who live in coastal areas generally live with low economic conditions as indicated by high incidence of poverty in this region. The economic activity of population who lives in coastal areas, particularly fishermen, depends on the utilization of the natural resources with low technology and limitation of capital. To improve the quality of human resources and reduce poverty in coastal areas, various community empowerment programs have been conducted. This article aims to examine the achievement of community empowerment programs and its challenge to achieve the program goals in Mapur Island, one of coastal area in Bintan Regency. The data used for this study are baseline studies of socio-economic aspects of coral reefs in Mapur Village conducted by PPK-LIPI in 2005 and 2015. The results shows that after a decade of community development programs implemented in the island of Mapur, the economic conditions of the population has improved as indicated by the increase of household income. Sources of income for the population also become more varying since economic opportunities open up more in the field of trade, services and transportation as a result of the development programs in coastal areas. However, the condition of human resources as indicated by educational level has not achieved the expected results. The education level of the population does not show significant changes over a decade. School dropout rates are quite high and the majority of the population only completed elementary school.
\end{abstract}

Keywords: Community Development, Coastal Areas, Human Resources, Welfare

\begin{abstract}
Abstrak
Wilayah pesisir di Indonesia mempunyai kekayaan sumber daya alam yang berlimpah, tetapi potensi tersebut belum dimanfaatkan secara optimal disebabkan oleh beberapa faktor, diantaranya rendahnya kualitas sumber daya manusia. Penduduk yang tinggal di wilayah pesisir pada umumnya hidup dengan kondisi ekonomi yang masih memprihatinkan diindikasikan dari tingginya kasus kemiskinan di wilayah ini. Kehidupan penduduk di wilayah pesisir, khususnya nelayan pada umumnya tergantung pada pemanfaatan sumber daya alam dengan menggunakan teknologi dan modal yang terbatas. Untuk meningkatkan kualitas sumber daya manusia dan mengurangi kemiskinan di wilayah pesisir berbagai program pemberdayaan ekonomi masyarakat telah dilakukan. Artikel ini bertujuan untuk mengkaji capaian program pemberdayaan masyarakat dan tantangan yang dihadapi dalam upaya meningkatkan kualitas sumber daya manusia di Pulau Mapur, salah satu wilayah pesisir di Kabupaten Bintan. Data yang digunakan dalam kajian ini berasal dari studi aspek sosial terumbu karang yang dilakukan oleh PPK - LIPI pada tahun 2005 dan 2015. Hasil kajian menunjukkan bahwa setelah satu dekade program pemberdayaan masyarakat dilaksanakan di Pulau Mapur, kondisi ekonomi penduduk telah mengalami perbaikan yang diindikasikan dari terjadinya peningkatan pendapatan rumah tangga. Sumber pendapatan penduduk semakin bervariasi karena munculnya peluang berusaha di bidang perdagangan, jasa, dan transportasi sebagai akibat dari adanya pembangunan wilayah pesisir. Namun demikian, kondisi sumber daya manusia dilihat dari tingkat pendidikan belum mencapai hasil yang diharapkan. Tingkat pendidikan penduduk tidak menunjukkan perubahan yang signifikan selama satu dekade. Angka putus sekolah cukup tinggi dan sebagaian besar penduduk berpendidikan SD ke bawah.
\end{abstract}

Kata Kunci: Pemberdayaan Masyarakat, Wilayah Pesisir, Sumber Daya Manusia, Kesejahteraan 


\section{PENDAHULUAN}

Wilayah pesisir adalah daerah pertemuan antara darat dan laut. Ke arah darat wilayah pesisir meliputi bagian daratan, baik kering maupun terendam air yang masih dipengaruhi sifat-sifat laut seperti pasang surut, angin laut, dan perembesan air asin. Sedangkan ke arah laut, wilayah pesisir mencakup bagian laut yang masih dipengaruhi oleh proses alami yang terjadi di darat seperti sedimentasi dan aliran air tawar yang disebabkan oleh kegiatan manusia di darat termasuk penggundulan hutan dan pencemaran. Wilayah pesisir memiliki arti strategis karena merupakan wilayah peralihan antara ekosistem darat dan laut yang berkesinambungan. Di wilayah pesisir terdapat sumber daya pesisir berupa sumber daya alam dan jasa lingkungan yang sangat kaya. Sumber daya tersebut meliputi: sumber daya yang dapat pulih (renewable resources) seperti ikan, mangrove, padang lamun dan terumbu karang; sumber daya tidak dapat pulih (nonrenewable resources) seperti mineral, pasir laut dan garam; dan jasa lingkungan kelautan (enviromental services) seperti wisata bahari dan transportasi laut serta benda berharga yang tenggelam di laut (Supriharyono, 2002; Direktorat Jenderal Kelautan, Pesisir dan Pulau-pulau Kecil-DKP, 2001).

Sumber daya alam di wilayah pesisir mempunyai arti penting bagi kegiatan perikanan, konservasi lingkungan, wisata bahari, dan kegiatan jasa lingkungan terkait untuk kesejahteraan masyarakatnya. Kekayaan sumber daya alam di wilayah pesisir ini apabila dipadukan dengan sumber daya manusia yang handal dan diperkuat dengan penerapan ilmu pengetahuan dan teknologi serta didukung dengan kebijakan pemanfaatan dan pengelolaan yang tepat bisa menjadi modal yang besar bagi pembangunan untuk meningkatkan kesejahteraan masyarakat. Namun sayangnya pemanfaatan sumber daya alam di wilayah pesisir belum optimal dan berkelanjutan.

Pemanfaatan potensi sumber daya alam di wilayah pesisir yang belum optimal dan berkelanjutan disebabkan oleh banyak faktor yang saling terkait satu sama lain yang dapat dikategorikan kedalam faktor internal dan eksternal. Faktor internal adalah faktorfaktor yang berkaitan dengan kondisi internal sumber daya masyarakat pesisir dan nelayan, seperti: (1) rendahnya tingkat penguasaan teknologi dan manajemen usaha, (2) pola usaha tradisional dan subsisten (hanya cukup memenuhi kehidupan jangka pendek), (3) keterbatasan kemampuan modal usaha, dan (4) kemiskinan masyarakat pesisir dan nelayan. Sedangkan faktor eksternal diantaranya: kebijakan pembangunan pesisir dan lautan yang lebih berorientasi pada produktivitas untuk menunjang pertumbuhan ekonomi yang masih bersifat sektoral dan parsial serta kurang memihak pada nelayan tradisional; kerusakan ekosistem pesisir dan laut karena kegiatan penangkapan illegal (penggunaan bom dan potas); serta eksploitasi dan perusakan terumbu karang (penambangan karang). Selain itu, rendahnya kesadaran arti penting dan nilai strategis pengelolaan sumber daya wilayah pesisir dan lautan secara terpadu juga menjadi penyebab kurang optimalnya pemanfaatan sumber daya alam di wilayah pesisir (Kusnadi, 2002. Mardiyanto 2010; Direktorat Pemberdayaan Masyarakat Pesisir, 2006).

Jumlah penduduk Indonesia yang tinggal di pesisir mencapai 161 juta jiwa atau sekitar 60 persen dari 250 juta penduduk Indonesia dan tersebar di 10.639 desa. Pada tahun 2008, penduduk miskin yang ada di wilayah pesisir kurang lebih 10 juta jiwa, terdiri dari 7,8 juta penduduk miskin dan 2,2 juta penduduk sangat miskin dan tahun 2011 bertambah menjadi 14,7 juta. Kemiskinan dan ketergantungan terhadap sumber daya pesisir dan laut seringkali mengakibatkan masyarakat melakukan kegiatan yang menurunkan kualitas sumber daya alam, seperti penebangan mangrove (untuk kayu bakar dan dijual) dan penangkapan ikan dengan menggunakan alat yang merusak ekosistem (Sekretariat Wakil Presiden Repubik Indonesia, 2011; Lasabuda, 2013).

Berbagai kajian menginformasikan bahwa tekanan kemiskinan yang melanda kehidupan masyarakat pesisir disebabkan oleh banyak faktor. Faktor-faktor tersebut tidak hanya berkaitan dengan fluktuasi musim ikan, keterbatasan sumber daya manusia, modal serta akses, jaringan perdagangan ikan yang eksploitatif terhadap nelayan sebagai produsen, tetapi juga disebabkan oleh dampak negatif modernisasi perikanan atau revolusi biru yang mendorong terjadinya pengurasan sumber daya laut secara berlebihan. Proses demikian masih terus berlangsung hingga sekarang dan dampak lebih lanjut yang sangat dirasakan oleh nelayan adalah semakin menurunnya tingkat pendapatan mereka dan sulitnya memperoleh hasil tangkapan. Studi tentang tingkat kesejahteraan hidup di kalangan nelayan juga menunjukkan bahwa kemiskinan dan kesenjangan sosial ekonomi atau ketimpangan pendapatan pada masyarakat pesisir merupakan persoalan krusial yang dihadapi dan tidak mudah untuk diatasi (Kusnadi, 2002; Satria, 2001; Suyanto, 2003; Widodo, 2011; Retnowati, 2011; La Sara, Abdul hamid and Safilu, 2011, Coultharda at all., 2011).

Berbagai kebijakan dan program telah dilaksanakan untuk meningkatkan kualitas sumber daya manusia dan mengentaskan kemiskinan di wilayah pesisir. Program 
pemberdayaan masyarakat pesisir yang sudah dilaksanakan sejak tahun 1980-an diantaranya:

- Motorisasi armada nelayan skala kecil yaitu program yang dikembangkan pada awal tahun 1980-an untuk meningkatkan produktivitas. Program motorisasi dilaksanakan di daerah padat nelayan, juga sebagai respons atas dikeluarkannya Keppres No. 39 Tahun 1980 tentang Penghapusan Pukat Harimau.

- Pembangunan prasarana perikanan berupa pelabuhan perikanan berbagai tipe dan ukuran di seluruh Indonesia, mulai dari kelas yang sangat kecil yaitu pangkalan pendaratan ikan hingga kelas yang terbesar yaitu pelabuhan perikanan samudera. Pelabuhan perikanan tersebut, dibangun di desadesa nelayan dan sentra-sentra produksi perikanan.

- Program yang berhubungan dengan konservasi dan rehabilitasi lingkungan hidup. Pembuatan karang buatan, penanaman kembali hutan bakau, konservasi kasawan laut dan jenis ikan tertentu, serta penegakan hukum terhadap kegiatankegiatan penangkapan ikan illegal dengan menggunakan bom, racun, dan alat tangkap ikan yang destruktif lainnya merupakan programprogram pembangunan yang secara tidak langsung mempengaruhi kesejahteraan nelayan.

- Dari sisi kelembagaan dikembangkan juga polapola usaha perikanan yang ditujukan untuk meningkatkan pendapatan nelayan. Berbagai upaya dilakukan untuk memfasilitasi dan mengembangkan koperasi perikanan, KUD Mina, kelompok usaha bersama perikanan, kelompok nelayan, kelompok wanita nelayan, dan organisasi profesi nelayan. Keberadaan lembaga - lembaga tersebut diharapkan menjadi katalisator percepatan kegiatan ekonomi masyarakat di wilayah pesisir.

- Program Pemberdayaan Ekonomi Masyarakat Pesisisr (PEMP) yang diluncurkan pada tahun 2001. Program ini secara umum bertujuan meningkatkan kesejahteraan masyarakat pesisir melalui penguatan permodalan, kelembagaan dan kegiatan usaha ekonomi produktif lainnya yang berbasis sumber daya lokal dan berkelanjutan. Program PEMP diinisiasi untuk mengatasi dampak kenaikan harga Bahan Bakar Minyak (BBM)

\footnotetext{
${ }^{1}$ Jumlah sampel survei pada tahun 2005 adalah 100 rumah tangga yang dipilih secara acak dari daftar rumah tangga yang ada di desa. Survei yang dilakukan pada tahun 2007, 2009, 2011, dan 2015 menggunakan sampel rumah tangga yang sama dengan survei tahun 2005.
}

terhadap perekonomian masyarakat pesisir, yang difokuskan pada penguatan modal melalui perguliran Dana Ekonomi Produktif (DEP). Pengelolaan DEP dilakukan oleh Lembaga Ekonomi Pengembangan Pesisir Mikro Mitra Mina (LEPP-M3) yang dibentuk sebagai perusahaan milik masyarakat pesisir (Douhuri, 2001; Nikijuluw, 2001; Rudiyanto, 2004; Yusran Siry, 2011).

Tulisan ini bertujuan untuk mengkaji capaian dari berbagai program dan kegiatan yang bertujuan untuk meningkatkan kualitas sumber daya manusia dan mengurangi kemiskinan penduduk, dengan mengambil kasus Pulau Mapur, salah satu wilayah pesisir di Kabupaten Bintan. Selain mengkaji capaian program, tulisan ini juga mengidentifikasi tantangan yang dihadapi dalam upaya meningkatkan sumber daya manusia di Pulau Mapur. Data yang digunakan adalah hasil survei aspek sosial terumbu karang yang dilakukan oleh PPK - LIPI di Desa Mapur, Kabupaten Bintan tahun 2005, 2007, 2009, 201, dan 2015. Pengumpulan data survei aspek sosial terumbu karang menggunakan kombinasi metode kuantitatif dan kualitatif. Data kuantitatif dikumpulkan melalui survei terhadap rumah tangga terpilih di Desa Mapur ${ }^{1}$. Sedangkan data kualitatif dikumpulkan melalui wawancara terbuka, FGD dan observasi kegiatan penduduk dan kondisi desa.

\section{PROGRAM PEMBERDAYAAN MASYARAKAT DI PULAU MAPUR}

Pulau Mapur adalah salah satu pulau yang ada di Kecamatan Bintan Pesisir, Kabupaten Bintan. Secara geografis, Pulau Mapur terletak antara $0^{0} 6 \mathrm{LU}-1^{0} 34$ LS dan $104^{0} \mathrm{BT}-108^{0} \mathrm{BT}$ dengan luas keseluruhan $484 \mathrm{~km}^{2}$. Luas daratan sebesar $44 \mathrm{~km}^{2}$, dan luas lautan $\pm 440 \mathrm{~km}^{2}$. Secara administratif, Desa Mapur terletak di sebelah utara Kabupaten Bintan yang berbatasan dengan Laut Cina Selatan. Di sebelah selatan berbatasan dengan Desa Kelong, berbatasan dengan Kecamatan Gunung Kijang di sebelah barat, dan berbatasan dengan Laut Cina Selatan di sebelah timur ${ }^{2}$.

Pada tahun 1950-an Pulau Mapur merupakan tempat singgah para nelayan dari luar pulau baik dari dalam provinsi maupun dari luar provinsi seperti nelayan Bugis dan Buton. Pada tahun 1960an, mulai berdatangan penduduk daratan Pulau Bintan pindah

${ }^{2}$ Direktori Pulau-pulau Kecil Indonesia. Diunduh dari http://www.ppk-kp3k.kkp.go.id/direktori-

pulau/index.php/public_c/pulau_info/2488 tanggal 23 September 2016. 
dan menetap di pulau Mapur untuk berkebun, dan melakukan kegiatan penangkapan ikan untuk memenuhi kebutuhan sendiri. Tahun 1970-an mulai berdatangan penduduk dari berbagai suku seperti Melayu, Bugis, Buton, dan China yang tinggal menetap di pulau ini. Sejak saat itu penduduk mulai memanfaatkan sumber daya laut dengan melakukan kegiatan perikanan tangkap. Pola pemukiman penduduk tidak menyebar secara merata di seluruh daratan pulau, tetapi mengelompok di sisi pantai sebelah selatan Pulau Mapur. Jumlah penduduk Pulau Mapur pada tahun 2013 sebesar 985 jiwa yang terdiri dari 415 laki laki dan 470 perempuan dengan kepadatan penduduk 193 jiwa per $\mathrm{km}^{2}$. Mata pencaharian penduduk yang utama adalah bekerja sebagai nelayan dan sebagian lainnya bertani dan bekerja dibidang jasa perdagangan (Widayatun dan Mujiyani, 2007; Widayatun dan Seftiani, 2015; BPS Kabupaten Bintan, 2014).

Dalam Rencana Pembangunan Jangka Menengah dan Daerah (RPJMD) disebutkan bahwa misi Kabupaten Bintan adalah "Mewujudkan pembangunan perekonomian daerah yang berbasis pada pengembangan sumber daya kelautan dan perikanan". Terkait dengan misi tersebut, pembangunan kelautan dan perikanan di Kabupaten Bintan diprioritaskan pada: (1) peningkatan produksi dan produkivitas perikanan untuk menjamin ketersediaan pangan dan bahan baku industri, (2) peningkatan pemenuhan kebutuhan konsumsi pangan (3) peningkatan nilai tambah, daya saing, dan pemasaran produk perikanan, dan (4) peningkatan kapasitas sumber daya masyarakat perikanan (Dinas Kelautan dan Perikanan Kabupaten Bintan, 2014).

Pulau Mapur adalah salah satu lokasi program pemberdayaan masyarakat perikanan Kabupaten Bintan. Program pemberdayaan yang bertujuan untuk meningkatkan kapasitas sumber daya masyarakat pesisir telah dilaksanakan di Desa Mapur sejak awal tahun 2000-an. Program - program tersebut diantaranya adalah: program bantuan kapal motor bagi kelompok nelayan. Program ini bertujuan untuk meningkatkan hasil tangkapan dan mendorong peningkatan produksi perikanan di Kabupaten Bintan. Bantuan yang diberikan kepada nelayan berupa kapal 3 GT dan 5 GT beserta alat tangkapnya.

Program pemberdayaan masyarakat yang dilaksanakan di Desa Mapur yang dimulai tahun 2004 adalah COREMAP (Coral Reef and Management Rehabilitation Program). Program ini bertujuan untuk melakukan pengelolaan sumber daya terumbu karang dan ekosistem terkait secara berkelanjutan untuk kesejahteraan masyarakat. Program COREMAP dirancang dengan melibatkan partisisipasi masyarakat mulai dari perencanaan sampai dengan pelaksanaan. Pada tahap awal kegiatan COREMAP lebih difokuskan pada upaya peningkatan kesadaran dan kepedulian pentingnya pelestarian terumbu karang dan penguatan kelembagaan yang ada di desa. Kegiatan COREMAP berikutnya adalah program peningkatan pendapatan masyarakat melalui kegiatan Mata Pencaharian Alternatif (MPA) dan bantuan sarana dan prasarana desa. Kegiatan MPA dilakukan dengan memberikan bantuan modal dan pelatihan kepada kelompok masyarakat untuk melakukan kegiatan ekonomi sesuai dengan potensi lokal. Terdapat beberapa kelompok yang telah mendapatkan bantuan, diantaranya: kelompok usaha pembuatan kerupuk, kelompok usaha makanan dan kue, kelompok usaha jahit menjahit dan kelompok usaha jaring apung (KJA) Kerapu. Selain itu, COREMAP juga memberikan bantuan prasarana fisik desa berupa pembangunan dermaga yang sampai saat ini masih dirasakan manfaatnya oleh masyarakat, karena dapat menunjang kegiatan ekonomi mereka. Nelayan yang melaut dapat berlabuh di dermaga, sehingga memudahkan proses loading hasil tangkap. Selain itu, keberadaan dermaga juga menunjang kegiatan perdagangan dan transportasi (Mujiyani dkk, 2007; Nagib, 2009; Asiati dan Nagib, 2011).

Program pembangunan lainnya di Desa Mapur yang secara tidak langsung juga berdampak pada kesejahteraan masyarakat adalah program pembangunan "Rumah Sehat" di pesisir. Di Desa Mapur terdapat sekitar 20 - 25 rumah tangga yang mendapat bantuan untuk membangun atau merenovasi rumah yang sehat. Setiap rumah tangga mendapat bantuan untuk membangun atau merenovasi rumah yang sehat senilai kuang lebih 20 juta rupiah.

\section{CAPAIAN PEMBANGUNAN SUMBER DAYA MANUSIA PULAU MAPUR DALAM SATU DEKADE (2005 - 2015)}

Gambaran tentang capaian pembangunan sumber daya manusia Pulau Mapur dilihat dari perkembangan kondisi sosial - ekonomi penduduk selama satu dekade (2005 - 2015) diantaranya: tingkat pendidikan penduduk, perubahan lapangan pekerjaan penduduk, serta tingkat pendapatan rumah tangga dan per kapita. Selain itu, akan dibahas juga perkembangan kegiatan penduduk di bidang kenelayanan.

\section{Pendidikan Penduduk}

Selama satu dekade (2005 - 2015), tingkat pendidikan penduduk Pulau Mapur belum menunjukkan peningkatan yang berarti, yaitu masih rendah. Pada tahun 2005 lebih dari 90 persen penduduk 
berpendidikan SD ke bawah. Proporsi penduduk yang tidak tamat SD mencapai lebih dari lebih dari separuh jumlah penduduk. Sementara itu proporsi penduduk yang berhasil menamatkan SMP ke atas kurang dari 9 persen. Sepuluh tahun kemudian pada tahun 2015, proporsi penduduk yang hanya berpendikan SD ke bawah masih cukup tinggi, sekitar 85 persen. Ini berarti selama satu dekade hanya terjadi penurunan jumlah penduduk yang tamat SD ke bawah sekitar 5 persen. Proporsi penduduk yang berhasil menamatkan pendidikan setingkat SMP ke atas hanya sekitar 15 persen atau terjadi peningkatan sekitar 6 persen selama kurun waktu 10 tahun (Diagram 1).

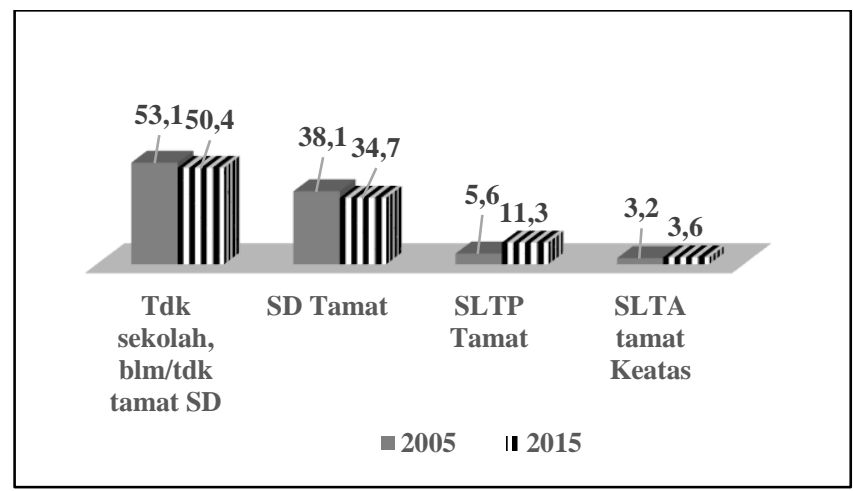

Sumber: - Survei Data Dasar Aspek Sosial Terumbu Karang PPK-LIPI 2005.

- Survei Data Dasar Aspek Sosial Terumbu Karang dan Ekosistem Terkait, PPK - LIPI, 2015.

\section{Diagram 1 \\ Distribusi Penduduk Berumur 7 Tahun Keatas Menurut Tingkat Pendidikan yang Ditamatkan, Desa Mapur Tahun 2005 -2015. (Persen)}

Rendahnya tingkat pendidikan penduduk Pulau Mapur dipengaruhi oleh beberapa faktor, antara lain sarana pendidikan yang terbatas serta motivasi dan aspirasi anak dan orang tua untuk meningkatkan pendidikan yang belum optimal. Pada tahun 2005, sarana pendidikan di Desa Mapur masih terbatas hanya pada tingkat SD dan SMP satu atap (SATAP). Sarana pendidikan tingkat lanjutan baik SMP maupun SMA hanya tersedia di kota kecamatan atau kabupaten yang berada di daratan Pulau Bintan. Pada tahun 2015 sarana pendidikan setingkat SMP sudah tersedia di Pulau Mapur. Untuk melanjutkan sekolah penduduk harus ke kota kecamatan atau kabupaten yang hanya dapat ditempuh melalui jalur laut, sedangkan angkutan reguler yang menghubungkan desa dengan lokasi sekolah lanjutan belum tersedia. Dengan keterbatasan sarana pendidikan di desa tersebut maka biaya untuk melanjutkan sekolah ke tingkat lanjutan relatif mahal. Uang tersebut digunakan untuk membayar berbagai keperluan antara lain tempat pemondokan, biaya hidup sehari-hari, dan biaya sekolah seperti membayar SPP, seragam sekolah, buku, dan iuran lainnya. Menurut penuturan informan pengeluaran biaya sekolah satu anak untuk tingkat SMP dapat mencapai sekitar Rp 500.000 per bulan. Uang tersebut digunakan untuk sewa kamar sebesar Rp 200.000 per bulan dan keperluan makan sehari-hari sekitar $\mathrm{Rp} 300.000$. Adapun untuk biaya sekolahnya bervariasi. Bagi mereka yang mempunyai saudara di kota biaya tersebut bisa ditekan menjadi separuhnya atau sekitar Rp 350.000. Biaya sekolah tersebut sangat berat untuk ditanggung oleh rata-rata penduduk Mapur (Widayatun dan Mujiyani 2007; Widayatun dan Seftiani, 2015).

Selain kendala lokasi tempat tinggal dan kemampuan pembiayaan, kendala lainnya yang tidak kalah penting adalah kurangnya motivasi orang tua maupun anak untuk melanjutkan ke tingkat sekolah yang lebih tinggi. Hal ini terlihat dari banyaknya penduduk di Desa Mapur yang relatif mampu tetapi tidak menyekolahkan anaknya ke tingkat yang lebih tinggi. Hal tersebut dipengaruhi oleh berbagai hal, salah satunya adalah sumber daya laut di sekitar pulau Mapur yang dianggap masih menjanjikan untuk memenuhi kehidupan yang layak menurut ukuran di desa. Selain itu, sebagian penduduk mempunyai anggapan bahwa menyekolahkan anak ke tingkat lebih tinggi cenderung merugikan karena adanya fakta bahwa mereka yang melanjutkan sekolah, setelah tamat tidak dapat memperoleh pekerjaan yang sesuai dengan tingkat pendidikan yang dimiliki.

Di samping rendahnya pendidikan formal, masyarakat juga kurang mempunyai ketrampilan yang berkaitan dengan kegiatan di luar perikanan. Masyarakat yang mempunyai keahlian di bidang perkebunan dan pertanian serta bidang lainnya masih relatif sedikit. Minat untuk belajar ketrampilan di bidang kegiatan non-kenelayanan juga relatif rendah. Kondisi tersebut menyebabkan masyarakat Pulau Mapur terus tergantung pada usaha-usaha yang berkaitan dengan pemanfaatan sumber daya laut, sementara potensi dan kekayaan laut yang berlimpah tersebut sudah mulai menurun karena pemanfaatan yang intensif.

\section{Pekerjaan Penduduk}

Seperti tipikal wilayah pesisir dan pulau kecil sebagian besar penduduk bekerja sebagai nelayan. Data menunjukan bahwa pada tahun 2005 sebagian besar (sekitar 76 persen) penduduk Pulau Mapur terlibat pada pekerjaan di sektor perikanan laut dan sisanya terdistribusi pada lapangan pekerjaan pertanian, perdagangan, jasa, dan pengolahan. Setelah satu dekade, data menunjukkan bahwa proporsi penduduk yang bekerja di sektor perikanan laut mengalami 
penurunan lebih dari 10 persen. Sebaliknya terjadi peningkatan proporsi penduduk yang bekerja pada lapangan pekerjaan perdagangan, industri pengolahan, trasportasi, dan konstruksi. Menurunnya proporsi penduduk yang bekerja di sektor perikanan mengindikasikan bahwa ketergantungan penduduk terhadap pemanfaatan sumber daya laut mulai menurun selama satu dekade. Penurunan ketergantungan tersebut seiring dengan adanya peluang untuk mendapatkan pekerjaan di luar sektor perikanan seperti perdagangan, industri, transportasi, dan konstruksi.

Peluang pekerjaan di bidang perdagangan di Pulau Mapur lebih tinggi dibandingkan dengan lapangan pekerjaan lainnya. Pada tahun 2005 proporsi penduduk yang bekerja di sektor perdagangan hanya sekitar 4,8 persen, meningkat hampir 2,7 kali lipat menjadi 13,1 persen pada tahun 2015. Gambaran peningkatan usaha di bidang perdagangan terindikasi dari semakin banyaknya usaha perdagangan skala rumah tangga di pulau ini seperti warung kebutuhan sehari hari serta warung makanan dan minuman. Pada tahun 2005 di Pulau ini hanya ada satu warung yang menjual kebutuhan sehari - hari (sembako). Keberadaan warung yang terbatas pada masa itu tidak terlepas dari adanya pedagang pengumpul ('tauke') ikan yang menyediakan barang - barang kebutuhan pokok untuk para nelayan. Kebutuhan rumah tangga nelayan seperti beras, minyak dan kebutuhan lainnya dipenuhi oleh "tauke" dan dibayar dengan pemotongan hasil penjualan ikan. Di samping keberadaan "tauke", daya beli masyarakat juga rendah karena pendapatan nelayan yang tidak menentu. Sepuluh tahun kemudian, pada tahun 2015 seiring dengan semakin memudarnya keberadaan "tauke", muncul usaha perdagangan mulai dari warung sembako hingga warung makanan dan minuman dan penjualan BBM. Kondisi ini menandakan adanya peningkatan kegiatan ekonomi penduduk Pulau Mapur.

Selain di perdagangan, peningkatan terjadi pada penduduk yang bekerja pada industri tumah tangga, transportasi, dan konstruksi. Penduduk yang bekerja pada industri rumah tangga ini pada umumnya adalah ibu - ibu yang membuat kue untuk dijual di warung atau dijajakan keliling kampung. Pada tahun 2005, usaha membuat kue belum banyak dilakukan oleh ibu ibu di Pulau Mapur. Sejalan dengan peningkatan kegiatan ekonomi penduduk, peluang usaha di bidang industri rumah tangga juga meningkat sehingga jumlah penduduk yang terlibat pada di bidang ini juga bertambah banyak. Semakin menggeliatnya kegiatan ekonomi penduduk Pulau Mapur juga terindikasi dari munculnya peluang pekerjaan di bidang transportasi dan konstruksi. Meskipun proporsinya masih rendah, pada tahun 2015 beberapa penduduk juga bekerja di bidang transportasi dan konstruksi (Tabel 1).

Tabel 1

Distribusi Penduduk Penduduk Pulau Mapur yang Bekerja Menurut Lapangan Pekerjaan Utama, Tahun 2005 dan 2015 (Persen)

\begin{tabular}{clcc}
\hline No & $\begin{array}{c}\text { Lapangan } \\
\text { pekerjaan } \\
\text { Utama }\end{array}$ & $\begin{array}{c}\text { Tahun } \\
2005\end{array}$ & $\begin{array}{c}\text { Tahun } \\
2015\end{array}$ \\
\hline 1 & Perikanan laut & 76,0 & 65,2 \\
2 & Pertanian & 5,4 & 5,4 \\
& Pangan & & \\
3 & Perdagangan & 4,8 & 13,1 \\
4 & Jasa & 4,8 & 4,3 \\
5 & Industri rumah & 3,2 & 6,5 \\
& tangga & & \\
6 & Transportasi & - & 2,2 \\
7 & Konstruksi & - & 3,3 \\
8 & Lainnya & 4,0 & - \\
& Jumlah & 100 & 100 \\
\hline
\end{tabular}

Sumber: - Survei Data Dasar Aspek Sosial Terumbu Karang PPK-LIPI 2005.

- Survei Data Dasar Aspek Sosial Terumbu Karang dan Ekosistem Terkait, PPK - LIPI, 2015.

Usaha di bidang pertanian merupakan salah satu peluang yang potensial untuk dikembangkan menjadi alternatif sumber pendapatan bagi penduduk Pulau Mapur, namun potensi ini belum dimanfaatkan oleh penduduk setempat. Proporsi penduduk yang bekerja di bidang pertanian tidak mengalami perubahan selama kurun waktu 10 tahun, hanya berkisar 5,4 persen. Salah satu faktor penyebab rendahnya jumlah penduduk yang berusaha di bidang pertanian adalah penghasilan dari bidang pertanian tidak sebanding dengan pendapatan di bidang penangkapan ikan. Sebagai nelayan, setiap hari dapat menghasilkan, berbeda dengan pekerjaan bertani yang harus menunggu sampai panen. Petani di Desa Mapur merupakan petani kebun dan petani tanaman pangan. Usaha tani kebun (kelapa) sudah diusahakan sejak pulau ini dihuni oleh penduduk. Namun demikian, usaha ini mengalami kemunduran seiring dengan semakin menurunnya produksi kelapa, dikarenakan tidak ada peremajaan tanaman. Usaha pertanian tanaman pangan berpotensi untuk dikembangkan. Jenis tanaman yang diusahakan adalah sayuran, palawija, dan buah-buahan seperti mangga, durian, alpukat, rambutan, dan jambu air. Peluang untuk memasarkan hasil pertanian masih luas, terutama untuk memenuhi kebutuhan lokal di pulau. Selain itu, pemasaran hasil pertanian ke wilayah pulau Bintan juga tidak menjadi kendala dengan telah adanya transportasi laut. 


\section{Pendapatan Penduduk}

Perkembangan pendapatan penduduk digambarkan dengan kenaikan rata-rata pendapatan rumah tangga dan per kapita. Pendapatan rumah tangga dalam penelitian ini dihitung dari penjumlahan pendapatan seluruh anggota rumah tangga yang bekerja di berbagai bidang pekerjaan seperti perikanan, pertanian, perdagangan dan industri rumah tangga. Sedangkan pendapatan per kapita dihitung berdasarkan penjumlahan pendapatan seluruh anggota rumah tangga dari berbagai sumber pendapatan dibagi dengan jumlah anggota rumah tangga. Dengan demikian pendapatan per kapita adalah pendapatan semua individu di Desa Mapur (anggota rumah tangga, kepala rumah tangga) baik yang bekerja, tidak bekerja ataupun belum bekerja.

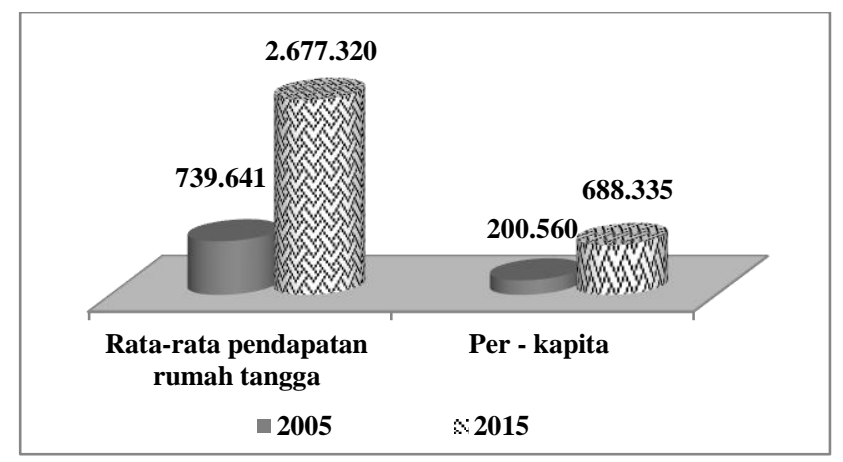

Sumber: - Survei Data Dasar Aspek Sosial Terumbu Karang PPK-LIPI 2005.

- Survei Data Dasar Aspek Sosial Terumbu Karang dan Ekosistem Terkait, PPK - LIPI, 2015.

\section{Diagram 2 \\ Perkembangan Rata-rata Pendapatan \\ Rumah Tangga dan Per - kapita Di Pulau Mapur 2005 - 2015 (Rupiah)}

Selama satu dekade antara tahun 2005 dan 2015 ratarata pendapatan rumah tangga di Pulau Mapur naik hampir 3,6 kali lipat, dari Rp 730.000,- pada tahun 2005 menjadi Rp 2,67 juta pada tahun 2015. Peningkatan rata-rata pendapatan rumah tangga penduduk Pulau Mapur ini tidak terlepas dari semakin menggeliatnya kegiatan ekonomi penduduk. Dengan semakin beragamnya kegiatan ekonomi penduduk maka sumber pendapatan rumah tangga juga semakin bervariasi. Pada tahun 2005, sumber pendapatan utama rumah tangga berasal dari kegiatan penduduk di bidang kenelayanan. Sepuluh tahun kemudian, sumber pendapatan rumah tangga semakin beragam dengan semakin terbukanya peluang usaha di bidang perdagangan dan industri rumah tangga. Peluang usaha tersebut memberikan kontribusi terhadap pendapatan rumah tangga. Jika sebelumnya para ibu hanya mengandalkan pendapatan suami dari hasil penangkapan, dengan adanya usaha perdagangan dan industri rumah tangga dapat memperoleh penghasilan sendiri yang bisa menambah pendapatan rumah tangga. Selain itu, tumbuhnya peluang kerja di bidang transportasi dan konstruksi juga berkontribusi terhadap peningkatan pendapatan rumah tangga. Pada tahun 2005, penduduk yang bekerja sebagai nelayan, pada musim paceklik (gelombang kuat) sebagian besar tidak bisa melaut. Selama tidak melaut untuk menutupi kebutuhan rumah tangga para nelayan berhutang pada "tauke". Namun kini dengan adanya peluang kerja di bidang non - kenelayanan (transportasi, konstruksi, dan jasa) di masa paceklik sebagaian nelayan beralih pekerjaan menjadi pekerja lepas seperti tukang batu dan buruh harian di bidang jasa transportasi (Widayatun dan Mujiyani, 2007; Widayatun dan Seftiani, 2015).

Selama satu dekade pendapatan per kapita penduduk Pulau Mapur juga mengalami peningkatan dari $\mathrm{Rp}$ 200.500 pada tahun 2005 menjadi Rp 688.335 pada tahun 2015. Nilai pendapatan per kapita penduduk Pulau Mapur pada tahun 2005 tersebut 1,3 kali lipat lebih tinggi dari nilai pendapatan per kapita yang ditetapkan sebagai batas kategori penduduk miskin di Kabupaten Kepulauan Riau, yaitu sebesar Rp 147.490 (BPS, 2004). Itu berarti bahwa pada tahun 2005 penduduk Pulau Mapur tidak ada yang masuk kategori miskin. Dengan peningkatan pendapatan per kapita pada tahun 2015 tersebut, maka pendapatan per kapita penduduk Pulau Mapur naik sekitar 2,2 kali lipat lebih tinggi dari pendapatan yang ditetapkan dalam kategori penduduk miskin di Provinsi Kepulauan Riau, yaitu sebesar Rp 313.277 (BPS Provinsi Kepulaun Riau, 2015). Dengan demikian selama sepuluh tahun, kehidupan penduduk Pulau Mapur semakin meningkat berada di atas garis kemiskinan. Ini artinya kebutuhan dasar papan, sandang, dan pangan penduduk Pulau Mapur semakin terpenuhi.

\section{Kegiatan Penduduk di Bidang Kenelayanan}

Nelayan di Pulau Mapur dapat dikategorikan ke dalam nelayan pantai (pesisir) dan lepas pantai (non-pesisir). Nelayan pantai melakukan kegiatan melaut secara harian (one day fishing) dari sekitar jam 5 pagi sampai sore hari antara jam 17.00 atau 18.00, atau berangkat sore hari dan pulang pagi dini hari. Wilayah penangkapan ikan di perairan sekitar Pulau Mapur di bawah 4 mil laut. Armada dan alat tangkap yang digunakan juga masih sederhana, yaitu perahu dengan body 28 kaki dan mesin 15-24 PK. Sebagian nelayan juga masih ada yang menggunakan perahu tidak bermotor. Alat tangkap yang digunakan adalah pancing, jaring, kelong, bubu, dan bento. Selama sepuluh tahun armada dan alat tangkap tersebut tidak 
mengalami peningkatan kecuali jumlah pemilik perahu bermotor.

Perahu yang digunakan oleh nelayan lepas pantai pada umumnya lebih baik dibandingkan dengan nelayan pantai, yaitu menggunakan perahu motor dalam dan sebagian telah dilengkapi dengan GPS. Alat tangkap yang digunakan adalah bubu dan pancing. Terdapat dua macam bubu yaitu bubu karang (bubu yang ukurannya kecil dengan ukuran sekitar $0,5 \mathrm{~m}$ ) dan bubu yang dipasang ke laut yang lebih dalam (bubu dengan ukuran lebih besar dengan ukuran sekitar $1 \mathrm{~m}$ ). Bubu karang dipasang dengan cara mengaitkan bubu ke karang, sedangkan bubu besar di pasang dilaut dengan menggunakan pemberat kayu dan batu karang mati. Bubu dipasang paling sedikit selama 3 hari. Untuk memperoleh hasil yang maksimal dalam penggunaan bubu, para nelayan pada umumnya telah mempunyai pengetahuan tentang keberadaan ikan. Bubu akan diletakkan di wilayah karang yang diperkirakan akan terdapat banyak ikan. Untuk mengenali letak bubu, sebagian nelayan mempunyai alat GPS yang dapat digunakan sebagai alat bantu. Bagi nelayan yang tidak mempunyai alat, mereka hanya menggunakan tandatanda alam untuk menandai letak bubu. Perkembangan selama sepuluh tahun terakhir pada nelayan non pesisir diantaranya adalah semakin banyaknya nelayan yang menggunakan GPS. Selain itu, sebagian nelayan nelayan non pesisir sudah melengkapi armada tangkapnya dengan alat untuk mendeteksi keberadaan ikan "fish finder".

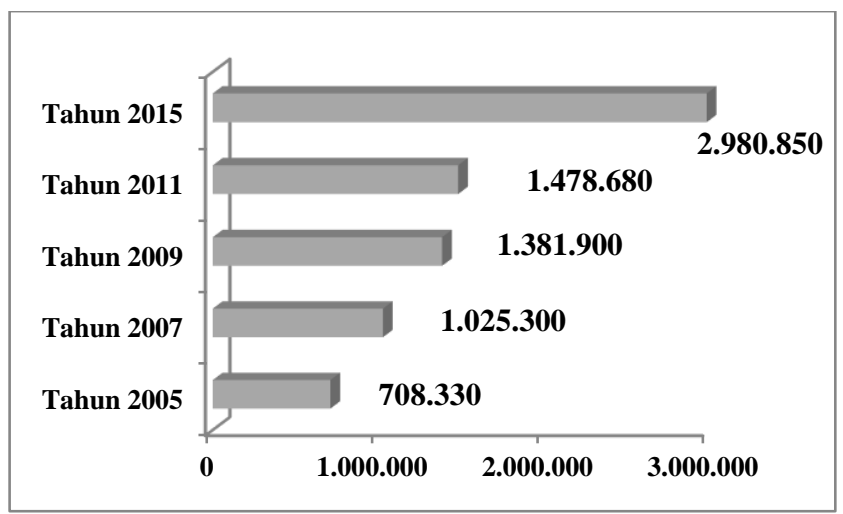

Sumber: Survei Aspek Sosial terumbu Karang 2005 - 2011, PPK LIPI.

Data Dasar Aspek Sosial Terumbu Karang dan Ekosistem Terkait, LIPI, 2015

Diagram 3

Perkembangan Pendapatan Rumah Tangga Nelayan di Pulau Mapur 2005 - 2015 (Rupiah)

\footnotetext{
${ }^{3}$ Pendapatan rumah tangga nelayan adalah pendapatan yang diperoleh dari anggota rumah tangga yang bekerja sebagai nelayan baik pekerjaan pokok maupun tambahan.
}

Pendapatan rumah tangga nelayan di Pulau Mapur mengalami peningkatan yang cukup pesat selama satu dekade $^{3}$. Pada tahun 2005 pendapatan rumah tangga nelayan sekitar Rp 708 ribu, meningkat 4 kali lipat menjadi Rp 2,98 juta pada pada tahun 2015. Pada periode 2005-2007 terjadi peningkatan pendapatan rumah tangga nelayan yang cukup besar, yaitu berkisar 3,5 persen per tahun. Pada periode 2011 sampai dengan 2015 kembali terjadi peningkatan yang cukup besar, yaitu sekitar 25 persen per tahun.

Peningkatan rata rata pendapatan nelayan di Pulau Mapur terkait dengan beberapa faktor yang dapat dikelompokkan menjadi dua, yaitu faktor internal dan eksternal. Faktor internal, di antaranya adalah teknologi alat tangkap dan wilayah tangkap serta biaya produksi. Sedangkan faktor eksternal adalah pemasaran dan permintaan ikan karang dan ikan laut dalam. Selama satu dekade telah terjadi peningkatan jumlah nelayan yang menggunakan perahu motor, yaitu dari 45 persen pada tahun 2005 menjadi sekitar 72,5 persen pada tahun 2015. Seiring dengan peningkatan armada tangkap, wilayah tangkap nelayan Pulau Mapur juga semakin jauh dari pantai. Berdasarkan hasil FGD didapatkan informasi bahwa sekitar tahun 2007 - 2009 wilayah tangkap nelayan bubu hanya sekitar 10-12 mil, namun pada tahun 2010 ke atas wilayah tangkap nelayan non - pesisir Pulau Mapur mencapai di atas 20 mil laut (Widayatun dan Mujiyani, 2007; Widayatun dan Sari Seftiani, 2015).

Faktor eksternal yang berpengaruh terhadap pendapatan rumah tangga nelayan adalah pemasaran dan permintaan ikan karang dan ikan laut dalam. Pola pemasaran hasil tangkapan nelayan Pulau Mapur telah mengalami perubahan yang cukup signifikan selama satu dekade. Pada tahun 1990-an sampai dengan awal tahun 2005 pemasaran ikan sangat tergantung pada "tauke" atau pengumpul ikan yang ada di desa. Ikan hasil tangkapan nelayan Pulau Mapur ditampung oleh “tauke' kemudian dipasarkan ke Kijang (pelabuhan dan pendaratan ikan di Kabupaten Bintan) untuk kemudian dikirim ke luar daerah (khusus ikan segar) dan ke pasar internasional, diantaranya Singapura dan Hongkong (khusus ikan karang hidup). Hubungan "patron client" antara nelayan dan "tauke" masih sangat kuat. Nelayan mendapat modal melaut dari "tauke" dengan keharusan menjual hasil tangkapan kepada "tauke" dengan harga ditentukan sepihak oleh "tauke". Selain biaya melaut, nelayan dan keluarganya juga menggantungkan biaya hidup sehari hari kepada 
'tauke'. Pada musim gelombang kuat, penghasilan nelayan berkurang sehingga untuk menutupi kebutuhan hidup sehari hari berhutang kepada "tauke". Pada musim gelombang tenang (musim panen ikan) hutang nelayan dibayar dengan memperhitungkan hasil tangkapan. Kondisi ini menyebabkan nelayan tidak memiliki posisi tawar untuk menentukan harga, sehingga pendapatan yang diterima menjadi rendah.

Setelah 10 tahun berjalan, berkembangnya teknologi komunikasi dan transportasi sebagai salah satu bagian dari pembangunan di wilayah pesisir berdampak pada memudarnya peran "tauke" dalam pemasaran ikan di Pulau Mapur. Adanya pembangunan dermaga dan pengadaan kapal angkutan umum semakin memudahkan masyarakat, khususnya nelayan untuk melakukan mobilitas ke daratan Pulau Bintan. Pola pemasaran ikan, khususnya ikan segar menjadi berubah. Para nelayan memasarkan sendiri hasil tangkapannya ke pedagang pengumpul di Kijang dengan menumpang kapal umum atau menggunakan perahu motor milik sendiri. Pemasaran yang dilakukan langsung oleh nelayan ke pedagang pengumpul di Kijang menguntungkan nelayan karena bisa mendapatkan harga yang baik sesuai harga pasaran yang berlaku. Sambil memasarkan hasil tangkapan, nelayan juga membeli kebutuhan sehari-hari dan belanja es untuk menyimpan hasil tangkapannya. Dengan adanya perkembangan teknologi komunikasi dan transportasi ini maka peran "tauke" lambat laun berkurang.

Untuk memasarkan ikan hidup sebagian nelayan masih menjual ke "tauke" di desa, dengan alasan untuk mengurangi risiko ikan mati atau hilang pada saat ditampung di keramba. Sampai saat ini masih terdapat sekitar 4 "tauke" penampung ikan hidup di Pulau Mapur, namun hubungan antara "tauke" dan nelayan sudah tidak lagi sebagai "patron dan klien", melainkan sebagai penjual dan pembeli, sehingga penentuan harga dadasarkan pada kesepakatan bersama antara nelayan dan "tauke". Hal itu disebabkan umumnya nelayan tidak lagi tergantung kepada "tauke" untuk memenuhi kebutuhan sehari-hari. Berkembangnya teknologi komunikasi memudahkan nelayan untuk memantau harga ikan hidup di pasaran (Kijang). Informasi harga ikan di pasaran dengan mudah dapat diperoleh oleh nelayan melalui hand phone (HP). Berubahnya pola pemasaran ini berdampak positif terhadap pendapatan rumah tangga nelayan (Widayatun dan Seftiani, 2015).

Permintaan ikan yang cukup tinggi juga mendorong peningkatan produksi ikan di Pulau Mapur. Permintaan ikan karang hidup untuk pasaran luar negeri cukup tinggi. Pemenuhan kebutuhan permintaan ikan karang pada pasar internasional diantaranya dipenuhi dari Kabupaten Bintan dan salah satu pemasoknya dari nelayan Pulau Mapur. Sementara itu permintaan ikan segar jenis ikan laut dalam umumnya untuk memenuhi kebutuhan pasar tingkat Kabupaten Bintan dan pasar tingkat regional. Permintaan pasar akan kebutuhan ikan karang hidup dan ikan segar ini menjadi peluang bagi nelayan Pulau Mapur untuk memanfaatkan potensi sumber daya laut yang ada sekaligus meningkatkan kesejahteraanya.

\section{TANTANGAN PEMBANGUNAN SUMBER DAYA MANUSIA PULAU MAPUR}

Wilayah perairan sekitar Desa Mapur dikelilingi oleh karang yang kaya berbagai jenis sumber daya laut (SDL). Wilayah ini menjadi daerah tangkapan (fishing ground) nelayan-nelayan dari Bintan Timur, bahkan nelayan dari luar Kepulauan Riau dan dari luar negeri. Jenis-jenis SDL yang dihasilkan dari perairan ini diantaranya adalah jenis ikan karang (kerapu, sunu), timun-timun dan ikan merah. Ikan karang jenis kerapu sunu pada umumnya dipasarkan dalam keadaan hidup. Selain itu, di sekitar wilayah Desa Mapur (sebelah Utara) merupakan perairan yang kaya berbagai jenis ikan laut dalam seperti ikan tenggiri, selar, kembung dan ikan putih. Berbagai jenis ikan tersebut pada umumnya dipasarkan dalam keadaan segar. Produksi ikan tenggiri akan melimpah pada saat musim angin utara dan ikan jenis selar pada musim angin barat dan timur. Jenis biota laut lain yang dihasilkan adalah cumi-cumi (sotong) dan ketam. Musim panen sotong, terjadi pada saat angin Timur, yaitu antara bulan April sampai dengan Juni, sedangkan ketam dapat dihasilkan setiap waktu, tidak mengenal musim.

Sumber daya alam yang melimpah di Pulau Mapur ini merupakan modal untuk menunjang peningkatan kualitas sumber daya manusia yang pada akhirnya berujung pada tercapainya kesejahteraan masyarakat. Berbagai upaya dan program untuk peningkatan kualitas sumber daya manusia di Pulau Mapur telah dan sedang dilakukan. Dalam pelaksanaannya berbagai upaya dan program tersebut belum mencapai hasil yang optimal yang diindikasikan dari masih terbatasnya kualitas sumber daya manusia, khususnya tingkat pendidikan dan ketrampilan penduduk. Kondisi perekonomian penduduk Pulau Mapur telah menunjukkan peningkatan. Meskipun demikian hal ini tidak menjamin tingkat kesejahteraan mereka akan terus meningkat di masa yang akan datang, jika sumber daya alam yang ada tidak dikelola secara baik yang didukung oleh sumber daya manusia yang berkualitas dan penerapan teknologi yang memadai. 
Bagi para nelayan di Pulau Mapur, pekerjaan menangkap ikan adalah pekerjaan turun-temurun tanpa pernah belajar untuk menjadi nelayan yang modern. Pada saat anak menginjak usia remaja, orang tuanya atau pamannya mulai mengajak melaut. Pemikiran mereka cukup sederhana, dengan membantu orang tua melaut, anak sudah bisa bekerja menghasilkan uang tanpa harus mempunyai pendidikan tinggi atau pergi merantau ke luar pulau atau daerah. Berlimpahnya potensi laut dan mudahnya mencari uang dengan menjual hasil laut menyebabkan masyarakat Pulau Mapur kurang mempunyai motivasi untuk meningkatkan pendidikan. Kondisi ini tidak hanya terjadi pada generasi tua, tetapi generasi muda pada saat ini juga kurang menyiapkan anak-anaknya untuk mendapat pendidikan di tingkat yang lebih baik. Hal ini menyebabkan tingginya angka putus sekolah di Pulau Mapur, terutama setelah tamat SMP (Widayatun dan Seftiani, 2015).

Gambaran sumber daya manusia di Pulau Mapur merupakan salah satu potret dari kondisi umum masyarakat yang tinggal di wilayah pesisir dan pulau kecil di Indonesia yang identik dengan kemiskinan dan pendidikan yang rendah. Secara empirik anak -anak di wilayah pesisir dan pulau kecil pada usia SD dan SMP angka putus sekolahnya cenderung tinggi. Masalah ketersediaan biaya untuk melanjutkan sekolah berkaitan erat dengan kondisi sosial dan ekonomi orang tua. Kebanyakan orang tua menyuruh anaknya bekerja setelah tamat dari SD dan SMP, membantu orang tua melaut atau menjadi buruh dan pekerja kasar lainnya. Hal ini juga tidak lepas dari kesadaran dan motivasi orang tua untuk menyekolahkan anaknya ke jenjang pendidikan yang lebih tinggi. Di samping itu, kemudahan akses untuk bekerja di sektor perikanan tangkap, tuntutan ekonomi keluarga, dan kesulitan dalam mencari peluang kerja lainnya sebagai akibat kegagalan pembangunan pedesaan, telah memperkuat barisan nelayan dengan tingkat kualitas sumber daya yang rendah. Dalam pikiran mereka, yang terpenting adalah bisa bekerja (menangkap ikan), mendapatkan penghasilan, dan bisa makan setiap hari (Sudrajat, 2003; Kusnadi, 2003; Indrawadi, 2009).

Untuk meningkatkan kualitas sumber daya manusia di wilayah pesisir dan pulau kecil, khususnya nelayan, memerlukan perhatian dan pendekatan yang multi dimensi. Tantangan yang terbesar adalah bagaimana meningkatkan kulitas sumber daya manusia di bidang perikanan sehingga kesejahteraan masyarakat meningkat. Asumsi yang ditegakkan adalah, kesejahteraan masyarakat pesisir dan pulau kecil akan dapat ditingkatkan jika kualitas sumber daya manusia, terutama tingkat pendidikan generasi muda nelayan, juga meningkat. Dengan berbekal ilmu pengetahuan yang cukup akan mengangkat harkat dan martabat kehidupan masyarakat di wilayah pesisir dan pulau kecil. Sementara itu berbagai fakta di lapangan menunjukkan bahwa sebagian masyarakat pesisir beranggapan bahwa pendidikan itu tidak terlalu penting karena ketrampilan yang digunakan oleh nelayan sudah diterima secara turun - temurun dan tidak perlu melalui proses pendidikan di sekolah. Selain itu, mengingat kondisi kehidupan nelayan yang tidak memungkinkan anak nelayan memasuki sekolah formal karena keberadaan anak nelayan dimaksudkan untuk membantu ayahnya mencari ikan ke laut.

Keberhasilan pendidikan penduduk dipengaruhi oleh beberapa faktor yang dapat dikategorikan menjadi dua, yaitu internal dan eksternal. Faktor internal meliputi kemampuan, minat, motivasi, nilai-nilai dan sikap, ekspektasi (harapan), dan persepsi individu tentang sekolah. Sedangkan faktor eksternal meliputi latar belakang ekonomi orang tua, persepsi orangtua tentang pendidikan, jarak sekolah dari rumah dan upaya yang dilakukan pemerintah (meliputi pemberian bantuan dan pengadaan sarana dan prasarana). Oleh karena itu, rendahnya tingkat pendidikan penduduk, termasuk banyaknya anak-anak putus sekolah di wilayah pesisir, bisa dikaji dengan melihat kedua aspek tersebut (Hasanudin, 2000; Lusiana, 2010).

Kondisi sumber daya laut di sekitar perairan Pulau Mapur telah terindikasi mengalami degradasi yang berpotensi menjadi kendala dalam meningkatkan kualitas sumber daya manusianya. Hal ini disebabkan lebih dari 75 persen penduduk pulau Mapur menggantungkan hidupnya dari kekayaan sumber daya laut. Jika sumber daya laut mengalami kerusakan maka sumber penghidupan masyarakat menjadi terganggu. Kegiatan perikanan tangkap menjadi sumber utama pendapatan rumah tangga, sementara sumber mata pencaharian lain sangat terbatas. Baseline studi aspek sosial terumbu karang yang dilakukan oleh LIPI mengangkat beberapa isu yang mengindikasikan telah terjadinya peningkatan degradasi sumber daya laut di perairan Pulau Mapur. Indikasi tersebut diantaranya adalah semakin jauhnya wilayah tangkap nelayan; beberapa biota laut di wilayah pesisir seperti ketam, cumi-cumi, dan udang yang sebelumnya dapat dengan mudah bisa diadapatkan oleh nelayan serang sudah mulai sulit; penyu yang dahulunya sering bertelur di pesisir Pulau Mapur pada musim tertentu, dalam satu tahun terakhir sudah tidak ada lagi, dan menurunnya hasil tangkap nelayan dalam setahun terakhir (Widayatun dan Seftiani, 2015).

Degradasi sumber daya laut di Pulau Mapur berkaitan dengan beberapa kegiatan manusia yang berpotensi mengganggu keseimbangan ekosistem pesisir dan laut 
di Pulau Mapur. Isu-isu berkaitan dengan kegiatan manusia yang mempengaruhi peningkatan degradasi sumber daya laut, diantaranya adalah:

- Ketergantungan kehidupan masyarakat lokal terhadap SDL cukup tinggi sehinga untuk menunjang kehidupan sehari-hari mereka melakukan penangkapan dengan menggunakan berbagai alat tangkap. Di samping itu, permintaan pasar baik lokal, domestik, regional maupun internasional yang tinggi juga memicu nelayan untuk lebih mengesklpoitasi SDL.

- Semakin intensifnya nelayan dari luar wilayah (Karimun, pantai utara Jawa) yang memanfaatkan sumber daya perairan di Pulau Mapur dengan menggunakan alat dan armada tangkap yang lebih canggih. Kapal-kapal tersebut bukan lagi usaha rumah tangga, tetapi sudah merupakan perusahaan perikanan. Jumlah armada tangkap nelayan dari luar ini semakin meningkat dalam beberapa tahun terakhir. Beroperasinya nelayan dari luar ini berpotensi menyebabkan terjadinya tangkap lebih (over fishing) dan telah menimbulkan konflik wilayah tangkap dengan nelayan lokal yang mengakibatkan nelayan lokal semakin terdesak.

- Polusi dari buangan residu kapal - kapal kargo yang berlayar di jalur internasional telah merusak keindahan pantai dan kemungkinan juga berdampak terhadap biota yang ada di dalamnya. Indikasi adanya polusi limbah kapal tersebut adalah banyaknya "tarbol" minyak yang sudah mengental seperti aspal di sepanjang pesisir pantai di Pulau Mapur. Selain itu, batu-batu putih yang menghiasi pantai pasir putih warnanya menjadi hitam karena telah tercemari limbah kapal. Adanya polusi ini telah mengakibatkan keseimbangan ekosistem terganggu sehingga berpengaruh terhadap kehidupan berbagai biota laut.

\section{KESIMPULAN}

Berbagai program yang bertujuan untuk memberdayakan masyarakat dan meningkatkan sumber daya manusia di Pulau Mapur telah dilakukan sejak tahun 2000-an. Program pemberdayaan masyarakat di pulau ini yang telah berjalan sampai satu dekade (10 tahun) adalah program COREMAP yang bertujuan untuk melakukan pengelolaan terumbu karang berbasis masyarakat untuk peningatan kesejahteraan. Kegiatan yang dilakukan yang dilaksanakan di desa antara lain adalah pemberian modal usaha dan ketrampilan pada kelompok masyarakat untuk melakukan kegiatan ekonomi serta pembangunan sarana fisik desa untuk menunjang kegiatan ekonomi penduduk.

Setelah satu dekade program pemberdayaan masyarakat Pulau Mapur dilakukan, kondisi sumber daya manusia di pulau ini masih belum membaik, dilihat dari tingkat pendidikan penduduknya. Dalam 10 tahun tingkat pendidikan penduduk belum menunjukkan peningkatan yang berarti, mayoritas (53 persen penduduk) tidak tamat SD. Padahal pendidikan yang didukung oleh penerapan teknologi yang memadai merupakan modal utama untuk mengoptimalkan pemanfaatan sumber daya laut sekaligus meningkatkan pendapatan masyarakat.

Tantangan yang dihadapi dalam upaya meningkatkan kualitas sumber daya manusia, khususnya berkaitan dengan pendidikan penduduk adalah rendahnya apresisasi tentang pentingnya pendidikan. Masyarakat, khususnya, nelayan belum memandang arti penting pendidikan bagi masa depan anak keturunannya. Mereka masih beranggapan bahwa untuk melakukan kegiatan penangkapan ikan tidak perlu mempunyai latar belakang pendidikan formal yang tinggi. Hal ini menyebabkan rendahnya motivasi untuk melanjutkan pendidikan ke jenjang yang lebih tinggi, sehingga angka putus sekolah cukup tinggi. Oleh karena itu, alternatif solusi untuk meningkatkan sumber daya manusia di wiayah pesisir dalam jangka pendek adalah pendidikan untuk anak nelayan tidak bisa diseragamkan, tetapi perlu disesuaikan dengan kondisi aktual masyarakat setempat. Model pembelajaran yang dikembangkan adalah pembelajaran yang berorientasi pada life skill (kecakapan hidup) yang memberikan bekal dasar dan latihan tentang nilai - nilai untuk bisa menanggulangi permasalahan dalam kehidupan. Salah satu contohnya adalah bagaimana anak nelayan dibekali kecakapan hidup untuk mengelola keuangan sehingga dapat mengurangi kebiasaan hidup yang cenderung konsumtif. Dalam jangka panjang, upaya untuk meningkatkan pendidikan formal masyarakat pesisir tetap dilakukan dengan membedah faktor faktor yang mempengaruhi rendahnya kesadaran dan kepedulian masyarakat tentang arti penting pendidikan.

Dalam 10 tahun terakhir, kualitas sumber daya manusia di Pulau Mapur dilihat dari kondisi ekonomi rumah tangga mengalami peningkatan. Pembangunan sarana dan prasarana perekonomian telah mendorong pemasaran hasil tangkapan nelayan menjadi lebih baik, sehingga mampu meningkatkan pendapatan masyarakat sekaligus juga meningkatkan produksi perikanan di tingkat kabupaten. Akan tetapi ancaman terhadap degradasi sumber daya laut yang diakibatkan adanya pemanfaatan berlebih over fishing oleh 
perusaahan perikanan skala nasional dan polusi limbah kapal perlu mendapat perhatian. Degradasi sumber daya laut berpotensi menjadi hambatan dalam meningkatkan kualitas sumber daya manusia Pulau Mapur karena sebagian besar masyarakat pulau ini menggantungkan hidupnya dari sumber daya laut. Pola pemberdayaan masyarakat pesisir yang berbasis masyarakat yang sudah dilaksanakan selama ini tidak dengan sendirinya bisa mengatasi permasalahan ini. Untuk mengatasi permasalahan adanya pemanfaatan berlebih sumber daya laut di Pulau Mapur oleh perusahaan skala nasional dan terjadinya polusi limbah kapal diperlukan kepedulian para stakeholders di tingkat regional dan nasional.

\section{DAFTAR PUSTAKA}

Asiati, Dewi dan Laila Nagib, 2011. Program COREMAP Di Desa Mapur Kabupaten Bintan: Manfaat dan Perubahan Pendapatan Masyarakat. Jakarta: Indonesia Pintar Publishing

BPS Kabupaten Bintan, 2014. Kecamatan Bintan Pesisir dalam Angka 2014. Bintan: Badan Pusat Statistik.

BPS Provinsi Kepulauan Riau, 2015. Profil Kemiskinan Provinsi Kepulauan Riau. Tanjung Pinang: Badan Pusat Statistik.

Coultharda Sarah , Derek Johnsonb , J. Allister McGregorc, 2011. Poverty, sustainability and human wellbeing: A social wellbeing approach to the global fisheries crisis. Global Environmental Change 21 (2011) 453 - 463.

Dinas Kelautan dan Perikanan Kabupaten Bintan, 2014. Profil DKP Bintan. Dinas Kelautan dan Perikanan Kabupaten Bintan

Direktorat Jenderal Kelautan, Pesisir dan Pulau-pulau KecilDKP, 2001. Naskah Akademik Pengelolaan Wilayah Pesisir. Departemen Kelautan dan Perikanan RI. Jakarta.

Dahuri, R. 2001. Pengelolaan Sumber Daya Wilayah Pesisir dan Lautan Secara Terpadu.

PT. Pradnya Paramitha, Jakarta

Hasanuddin, B. 2000. Diundur Hingga 2009, Penuntasan Wajib Belajar Sembilan Tahun. [online]. http://edukasi.kompas.com/read/201 1/03/03/ Diundur-Hingga-2009- Penuntasan-Wajib-Belajar Sembilan-Tahun. Harian Kompas. Edisi 3 Maret. Tanggal akses 06 Maret 2011.

Indrawadi, 2009. Nasib Nelayan dan Potensi Kelautan. http://www.geocities.com/minangbahari/artikel/na sibnelayan.html. Diakses 20 November 2016.
Kementerian Kelautan dan Perikanan Republik Indonesia. Direktori Pulau-pulau Kecil Indonesia. Diunduh dari http://www.ppkkp3k.kkp.go.id/direktoripulau/index.php/public_c/ pulau_info/2488 tanggal 23 September 2015

Kusnadi, 2002. Akar Kemiskinan Nelayan. Yogjakarta: LKIS

2003. Nelayan: Strategi Adaptasi dan Jaringan Sosial. Cetakan 1. Bandung: Humaniora Utama Press.

2009. Keberdayaan Nelayan dan Dinamika Ekonomi Pesisir. Yogjakarta: AR -Ruzz

Lasabuda, Ridwan, 2013. "Pembangunan Wilayah Pesisir dan Lautan Dalam Perspektif Negara Kepulauan Republik Indonesia": Jurnal Ilmiah Platax Vol. 12.

La Sara, Abdul Hamid dan Safulu, 2011. "Empowering Coastal Community By Implementing Natural Resources management (Case Study in South Sulawesi, Indonesia)". Journal of Coastal Development, Volume 14, Number 3, June 2011 : $202-213$.

Lusiana, 2010. Faktor-Faktor Sosial Ekonomi Yang Berpengaruh Terhadap Motivasi Anak Nelayan Untuk Sekolah. [online]. http://repository.usu.ac.id/bitstream/ 123456789/17858/7/Cover.pdf. Tanggal akses 20 Oktober 2016.

Mardiyono, 2014. Persepsi dan Partisipasi Nelayan Terhadap Pengelolaan Kawasan Konservasi Laut Kota Batam (Tesis). Universitas Diponegoro.

Mujiyani, Laila Nagib dan Zainal Fatoni, 2007.

Kondisi Sosial Ekonomi Masyarakat di Lokasi COREMAP II, Desa Mapur, Kabupaten Bintan, Hasil BME. Jakarta: COREMAP - LIPI.

Nagib, Laila, 2009. Perkembangan Pendapatan Masyarakat di Lokasi COREMAP II, Desa Mapur, Kabupaten Bintan, Hasil BME. Jakarta: COREMAP - LIPI.

Nikijuluw, Victor, 2001. Aspek sosial Ekonomi Masyarakat Pesisir dan Strategi pemberdayaan Mereka Dalam Konteks Pengelolaan Sumber Daya Pessir Terpadu. Proceding Pelatihan Pengeloaan Wilayah Pesisir Terpadu. Bogor: IPB 29 Okttober -3 November 2001.

Retnowati, Endang, 2013. Nelayan Indonesia Dalam Pusaran Kemiskinan Struktural (Perspektif Sosial, Ekonomi Dan Hukum). Perspektif. Vol XVI No. 3

Sekertariat Wakil Presiden RI, 2011.

"Pendataan Rumah Tangga Miskin di Wilayah Pesisir/Nelayan". Jakarta: Tim Nasional Percepatan Penanggulangan Kemiskinan. 
Rudyanto, Arifin, 2004. Kerangka Kerjasama Dalam Pengelolaan Sumber Daya Pesisir dan Laut. Paper dipresentasikan pada Sosialisasi Nasional Program MFCDP, 22 September 2004.

Sudrajat, Jajat, 2013. "Potensi dan Problematika Pembangunan Wilayah Pesisir di Kalimantan Barat'. Jurnal Social Economic of Agriculture, Volume 2, Nomor 1, hlm 29-41.

Supriharyono, 2002. Pelestarian Dan Pengelolaan Sumber Daya Alam Di Wilayah Pesisir Tropis. Jakarta: PT. Gramedia Pustaka Utama.

Yusran Siry, Hendra, 2011. "In search of appropriate approaches to coastal zone management in Indonesia". Jurnal Ocean \& Coastal Management 54 (2011). homepage: www.elsevier.com/locate/ocecoaman
Widayatun dan Mujiyani, 2007. Data Dasar Aspek Sosial Terumbu Karang: Desa Mapur Kecamatan Bintan Timur, Kabupaten Bintan. Jakarat: LIPI Press.

Widayatun dan Sari Seftiani, 2015. Data Dasar Aspek Sosial Terumbu Karang dan Ekosistem Terkait di Kabupaten Bintan. Jakarta: COREMAP - CTI LIPI.

Widodo, 2011. "Strategi Nafkah Berkelanjutan Bagi Rumah Tangga Miskin di Daerah Pesisir". Makara Sosial Humaniora, Vol 15. No. 1: 10-20. 
Jurnal Kependudukan Indonesia | Vol. 11, No. 2, Desember 2016 | 119-132 